


\title{
Protection of property rights of citizens in the conditions of foreign military aggression: political and legal experience of Ukraine
}

\author{
DOI: https://doi.org/10.46398/cuestpol.3969.11
}

\author{
Filatov Viktor * \\ Sergey Herasymchuk ** \\ Oksana Zuieva ${ }^{* * *}$ \\ Oksana Tuieva **** \\ Dmytro Kartsyhin *****
}

\section{Abstract}

The aim of the research is a comprehensive analysis of the problem of protecting property rights against a terrorist threat and finding ways to solve it. The article deals with the main problems of protection of property rights under conditions of external military aggression in Ukraine. The authors, with the example of a separate case, analyses the problematic aspects of renewing and granting property rights to citizens residing in the temporarily occupied territory of Ukraine. Methodologically, it is a documentary research. It is concluded that the law and judicial practice of the protection of property rights in the example of the right to compensation for damaged homes may prove insufficient on its own. The weaknesses of Ukrainian legislation in compensation for damage caused to citizens in conditions of armed conflict and terrorist activity are discussed in detail. Finally, it emphasizes the role of transitional justice in improving the law and practice of resolving disputes overcompensation for moral and material damage under the conditions of occupation of certain territories of Ukraine.

* Filatov Viktor, Candidate of Juridical Sciences, Associate Professor of the Department of Civil, Commercial and Environmental Law University of Customs and Finance, Dnipro, Ukraine. ORCID ID: https://orcid.org/oooo-0oo2-8059-3736. Email: filatov_viktor@ukr.net

** Sergey Herasymchuk, Candidate of Juridical Sciences, Senior Lecturer of the Department of Civil, Commercial and Environmental Law University of Customs and Finance, Dnipro, Ukraine. ORCID ID: https://orcid.org/oooo-0oo2-4038-3048. Email: herasymchukss@gmail.com

*** Oksana Zuieva, Candidate of Juridical Sciences, Associate Professor of the Department of Civil, Commercial and Environmental Law University of Customs and Finance, Dnipro, Ukraine. ORCID ID: https://orcid.org/oooo-ooo1-8054-1509. Email: oksana_zueva@i.ua

**** Oksana Tuieva, Candidate of Juridical Sciences, Associate Professor of the Department of land and agrarian law The Yaroslav Mudryi National Law University, Kharkiv, Ukraine. ORCID ID: https:// orcid.org/o0oo-0003-0474-4034. Email: Ksushatu67@gmail.com

***** Dmytro Kartsyhin, Post-graduate student of the Department of Civil, Economic and Environmental Law at the University of Customs and Finance, Dnipro, Ukraine. ORCID ID: https://orcid.org/oooooo01-7477-9123. Email: phoenix.dmytro@icloud.com 
Keywords: damage compensation; external military aggression in Ukraine; protection of property rights; occupation of certain territories; transitional justice.

\section{Protección de los derechos de propiedad de los ciudadanos en condiciones de agresión militar extranjera: experiencia política y legal de Ucrania}

\section{Resumen}

El objetivo de la investigación es un análisis integral del problema de la protección de los derechos de propiedad ante una amenaza terrorista y encontrar formas de solucionarlo. El artículo trata los principales problemas de protección de los derechos de propiedad en condiciones de agresión militar externa en Ucrania. Los autores, con el ejemplo de un caso separado, analizan los aspectos problemáticos de renovar y otorgar derechos de propiedad a los ciudadanos que residen en el territorio temporalmente ocupado de Ucrania. En lo metodológico se trata de una investigación documental. Se concluye que la ley y la práctica judicial de la protección de los derechos de propiedad en el ejemplo del derecho a indemnización por viviendas dañadas puede resultar insuficiente por si sola. Se discuten en detalle las debilidades de la legislación ucraniana en el ámbito de la indemnización por los daños causados a los ciudadanos en condiciones de conflictos armados y actividad terrorista. Por último, se hace hincapié en el papel de la justicia de transición en la mejora de la legislación y la práctica de resolver controversias sobre indemnización por daños morales y materiales en las condiciones de ocupación de determinados territorios de Ucrania.

Palabras clave: indemnización por daños; agresión militar externa en Ucrania; protección de los derechos de propiedad; ocupación de determinados territorios; justicia transicional.

\section{Introduction}

In early 2014, Ukraine faced a number of social upheavals, which brought about radical changes in public relations and forced the authorities to respond promptly to internal threats, and subsequently to external ones. If you look at Ukraine through the prism of transitional justice, then one should state the uniqueness of the state, because in a rather short time, 

and legal experience of Ukraine

it has passed a post-authoritarian period and was in the face of foreign military aggression on the part of Russia. As a result, the state faced the socalled "post-conflict period", which brought about the necessity to revise the doctrine of national security as a whole. Over the past five years, Ukraine managed not only to take control of the situation, but also to modernize in an integrated manner the security sector and adapt national legislation to transitional justice. However, unfortunately, some aspects were neglected by the authorities, primarily because the practice of applying international humanitarian law was not implemented.

One of the key issues today is protecting the property rights of citizens in conditions of an armed conflict. First of all, it is about citizens whose property was damaged, demolished, destroyed in temporarily occupied territories or in settlements located on the line of collision. These are destroyed housing, lost business, damaged property, and the inability to use property in the temporarily occupied territory. The scale of this problem is very much significant, since almost every internally displaced person has suffered certain property losses.

At the present stage of development, more and more of such individuals turn to the European Court of Human Rights with claims to recognize such harm and its reimbursement. First of all, this is due to the lack of effective mechanisms for protecting citizens' property rights in Ukraine in the face of terrorist threats and external military aggression. For the most part, such appeals are possible with the participation of human rights organizations that implement projects in the field of protecting the rights of internally displaced persons at the expense of international financial contributors. Unfortunately, the state has not yet shown an active position in resolving this issue.

Therefore, the main purpose of this article is to systematize the main problematic aspects of protecting property rights of citizens in the context of external military aggression and to formulate proposals to resolve this problem in Ukrainian society. Therefore, it is proposed: to consider the essence of the problem on the example of a separate case from the practice of human rights defenders; identify on this basis the shortcomings and gaps in Ukrainian legislation; to propose clear solutions and recommendations that will create the proper mechanisms for restoring and ensuring the property rights of citizens in conditions of an armed conflict. The research should be conducted taking into account the principles and directions of transitional justice, at the stage of which the modern Ukrainian state is. 


\section{Literature review}

Since the beginning of the conflict in eastern Ukraine, domestic scholars have begun to analyze issues of political and legal resistance to external military aggression by Russia. In particular, it should be noted the work of S. P. Kolisnyk, which reveals the formation of state policy against terrorism and separatism (Kolisnyk, 2019). It is also worth noting the work of O. I. Ostapenko, who conducts a comprehensive analysis of the problems of combating terrorism in the armed conflict in the Donbass (Ostapenko, 2017). These scholars have made a significant contribution to the development of theoretical principles of domestic legal science. Also in the process of writing this article, the authors used the regulations of current legislation and the practice of their application. These are legislative acts that were adopted after the beginning of the armed conflict. The practical case is presented by the materials of human rights non-governmental organizations involved in restoring the rights of victims of terrorist activities in Donbass.

\section{Materials and methods}

The analysis of the problems outlined above requires using a complex of general scientific and special legal methods of cognition. Thus, the dialectical method has been used to clarify the factors that led to the imperfection of Ukraine's legislation on the protection of property rights of citizens in the context of external military aggression, as well as the identification of trends in the development of such legislation. With the help of the systemstructural method, the analysis of the main shortcomings of the judicial practice concerning the consideration of cases on the protection of property rights in the zone of armed conflict has been conducted.

Using the formal-logical method, the theoretical positions of the article, in particular its categorical apparatus, are formulated. Using the methods of analysis and synthesis allowed to propose the ways to resolve the problem of ineffectiveness of protecting property rights of citizens in the temporarily occupied territories and on the line of collision. Methods of synthesis and forecasting are used in the formulation of the conclusions to this article. In general, the above mentioned methodology contributed to the complex analysis of the problem and the formation of the results which have theoretical and practical significance.

\section{Results and discussion}

From the beginning of the conflict, it became clear that the problem of systematic violations of fundamental human rights in the area of hostilities 
poses an enormous threat to the normal functioning of the authorities and public institutions. The neglect of pro-Russian mercenaries of elementary standards of treating people and their property in conditions of an armed conflict and the principle of humanism has once again demonstrated the whole threat to the situation (Ostapenko, 2017). As a result, at the legislative level, the state authorities begin to form the basis of the policy of protecting the rights of internally displaced persons and those who, due to certain circumstances, remained in the temporarily occupied territories of the Donbas and Crimea. At that time, the key legislative acts were:

- Law of Ukraine of April 15, 2014 "On ensuring the rights and freedoms of citizens and legal regime in the temporarily occupied territory" (On ensuring the rights and freedoms of citizens and legal regime in the temporarily occupied territory, 2014). This document became the main guarantee of the protection of the rights and freedoms of Ukrainian citizens who at the time of annexation lived in the Crimea, including property rights. Thus, this law consolidated the exclusive right of the state, individuals and legal entities to property, including land in the temporarily occupied territory, regardless of whether they left the territory or not. An additional guarantee was also the establishment of the principle of legitimacy of the acquisition and termination of ownership of this property, exclusively in accordance with the procedure established by the legislation of Ukraine. In other words, the state not only disapproved the annexation of territories, but also clearly outlined its priorities in temporarily occupied territories, including the protection of property rights;

- The Law of Ukraine of September 2, 2014 on "On Interim Measures for the Period of the Anti-Terrorist Operation" (On interim measures for the period of the anti-terrorist operation, 2014). Several important aspects are identified in this legal act. In particular, the authorized right of using by economic entities the property transferred to them in the course of movement from temporarily occupied territories. It should also be noted that there has been implemented the formalization of the right of an individual to open inheritance not at the place of the property, that is, in the occupied territory, but at the place of submission of the corresponding application on the controlled territory of Ukraine. This contributed to the removal of obstacles to the implementation of inherited property rights;

- Law of Ukraine of October 20, 2014 "On ensuring the rights and freedoms of internally displaced persons" (On ensuring the rights and freedoms of internally displaced persons, 2014). In essence, this law outlined the status of a new category of citizens of Ukraine - an internally displaced person. Among other norms, it is important to establish a moratorium on the repayment of the principal amount 
of mortgage and accrued interest in the event the property is located on a temporarily occupied territory. It is quite fundamental that the stated law declares the principle of state participation in the process of restoration and further protection of the rights of settlers, in particular those owning the property;

- Statement of the Verkhovna Rada of Ukraine of April 21, 2015 "On the Resistance to the Armed Aggression of the Russian Federation and Overcoming Its Consequences" (On the Suppression of Armed Aggression of the Russian Federation and Overcoming its Consequences, 2015). This document was primarily of political and legal significance, since the Parliament of Ukraine condemned the foreign military aggression, paying attention to its negative consequences, in particular, of property character. Thus, they focused their attention on the problem of appropriating the property of the state and citizens, the destruction and theft of this property, its illegal nationalization, and large-scale damage. We believe that this is a rather important stage in the further resolution of the conflict and establishing guilty persons who must necessarily be held liable for the criminal acts;

- Law of Ukraine of June 12, 2015 "On the Legal Framework of Military Status" (On the Legal Regime of Military Status, 2015). Theimportance of this document was that the principle of full compensation of the value of forcibly alienated property was established. That is, in case of using the property of individuals for the needs of the Armed Forces of Ukraine, its value in the future should be compensated by the state. In addition, the law established the principle of compensation for property losses incurred during the military state. These are quite significant guarantees for citizens of Ukraine which indicate that the state does not relinquish responsibility for the property consequences of an armed conflict.

It should be emphasized that the protection of property rights of citizens in the conditions of external military aggression requires the activation of rule-making at the level of by-laws as well, because at this very level there is detailed elaboration of legislation norms. The executive power is also responsible for implementing the state policy in the human rights sphere. In view of this, the following sub-legal acts that were adopted as part of developing the system of guarantees of property rights protection can be cited:

- Resolution of the Cabinet of Ministers of Ukraine dated October 31, 2012 "Some issues of full compensation for property forcibly alienated under the legal regime of military or state of emergency" (Some issues of full compensation for property forcibly alienated under the conditions of the legal regime of martial law or the state 
Filatov Viktor, Sergey Herasymchuk, Oksana Zuieva, Oksana Tuieva y Dmytro Kartsyhin Protection of property rights of citizens in the conditions of foreign military aggression: political and legal experience of Ukraine

of emergency, 2012). The document contains the appropriate guarantees of compensation for the value of destroyed property, but only in a wartime situation. In Ukraine, such a situation was introduced only for a short time, and only when the active phase of armed confrontation ended. That is, the reimbursement mechanism was not an effective means of protecting property rights;

- Resolution of the Cabinet of Ministers of Ukraine dated October 1, 2014 "On Approval of the Procedure of Using the Funds Received from Individuals and Legal Persons to Provide One-Time Cash Assistance to Victims and Internally Displaced Persons" (On Approval of the Procedure for Using the Funds Received from Individuals and Legal Persons to Provide One-Time Cash Assistance to Victims and Internally Displaced Persons, 2014). The document contains certain guarantees for settlers, including one-time monetary compensation. Nevertheless, this is not enough to solve housing problems, since there is only money to meet the individual needs of everyday life;

- Resolution of the Cabinet of Ministers of Ukraine dated October 1, 2014 "On the provision of monthly targeted assistance to internally displaced persons to cover residential expenses, including housing and communal services" (About the provision of monthly targeted assistance to internally displaced persons to cover the cost of living, including for payment of housing and communal services, 2014). The funds that migrants receive under this decree are mainly directed towards the payment of utilities.

Moreover, there are many cases of refusal to pay such assistance which is mainly due to the unequal interpretation of the rules of law. For instance, a retired pensioner may be refused on the grounds that she lives in a son's home, and hence belongs to his family. Although, according to the Family Code of Ukraine, a single person is an independent family;

- Resolution of the Cabinet of Ministers of Ukraine dated November 7, 2014 "On approval of the list of settlements on the territory which the state authorities temporarily do not exercise their powers over and the list of settlements located on the line of collision" (On approval of the list of settlements on the territory of which the state authorities temporarily do not exercise their powers and the list of settlements located on the line of collision, 2014). This document is a prerequisite for establishing a causal link between the destroyed property and the armed conflict. However, in the absence of legal compensatory mechanisms, it is not able to promote the property rights protection of inhabitants of the occupied territories;

- The Resolution of the Cabinet of Ministers of Ukraine dated April 18, 2018, entitled "Providing housing for internally displaced persons 
who defended Ukraine's independence, sovereignty and territorial integrity" (The issue of providing housing for internally displaced persons who defended the independence, sovereignty and territorial integrity of Ukraine, 2018). This decree is a sufficiently effective means of protecting property rights, in particular the right for housing, but only of those settlers who joined the Armed Forces of Ukraine and with arms in their hands defended Ukraine's independence. The document introduces a mechanism for allocating subventions from the state budget for estate purchase for such persons in the territory under the control of Ukraine.

It should be noted that at the subordinate level there are also no effective mechanisms for ensuring the protection of property rights of citizens in conditions of an armed conflict. It negatively affects not only the sociopolitical situation of internally displaced persons. The fact is that due to such a policy, the state increases the social alienation of migrants in Ukrainian society and their mistrust in the state power. One of the reasons for such a situation not long ago was the lack of a clear position of Ukraine regarding the position of the aggressor state at the legislative level. As a result, the responsibility for violated property rights of citizens in conditions of the armed conflict was not held, because the subject that should compensate harm caused to people was unknown.

A positive step in solving this problem was the Law of Ukraine dated January 18, 2018, "On the peculiarities of the state policy to ensure the state sovereignty of Ukraine in temporarily occupied territories in the Donetsk and Luhansk oblasts" (On the peculiarities of the state policy to ensure the state sovereignty of Ukraine in the temporarily occupied territories in the Donetsk and Luhansk oblasts, 2018). The document for the first time recognized Russia as an aggressor state. In addition, the law contains several norms related to the protection of property rights of citizens in the context of external military aggression. First, the exclusivity of the property rights of citizens and the state to the property located in the temporarily occupied territory is enshrined. This allows you to appeal to the disputing parties regarding the restoration of property rights.

On the other hand, the law contains a norm according to which the responsibility for material or non-pecuniary damage inflicted on Ukraine as a result of the armed aggression of the Russian Federation is held by Russia, as well as by self-proclaimed republics in accordance with the principles and norms of international law. In other words, Ukraine essentially relinquishes its obligation to compensate property damage caused by an armed conflict, imposing such obligations on the aggressor state. That is, there is a legal conflict. On the one hand, Ukraine recognizes the occupied territories as its territories, and the citizens who live on them - are citizens of Ukraine, and on the other hand, it shifts away from the obligation to guarantee the protection of the property rights of such citizens. 

and legal experience of Ukraine

The situation is also complicated by the imperfection of legal acts of a strategic nature in the area of protection of migrants' rights. It should be noted that the policy aimed at the complex solution of the problems of the latter, in general, until recently, was situational in nature. That is, there were separate managerial decisions to overcome this or that problem, but there was no systematic vision of the situation as a whole. As a result, politics was ineffective, and misunderstandings were only deepening. Only at the end of 2017, several conceptual documents were adopted. First of all, we should emphasize the importance "Strategy of integration of internally displaced persons and implementation of long-term decisions on internal movement for the period until 2020" (On Approval of the Strategy for the Integration of Internally Displaced Persons and Implementation of LongTerm Decisions on Internal Movement for the Period up to 2020, 2017).

This document is quite important, because it contains a mechanism for protecting property rights of migrants which includes the following elements: documenting cases of property destruction by creating an appropriate state register of destroyed property; introducing criteria for assessing property damage and methods of compensation; restoration of lost documents confirming ownership; legal aid. Implementation of this mechanism in accordance with the rules of the strategy requires the application of a set of regulatory, financial, credit, tax and other measures. The result of implementing the planned measures should be the return of control over the lost property, or in the event of its destruction - the receipt of appropriate compensation. At present, the rules of this strategy are being implemented quite slowly and for the most part remain declarative.

It should be noted that the above-mentioned problems are accompanied by the lack of practical development of applying the norms of international humanitarian law in Ukraine. The state was not ready for external military aggression, and as a result, it did not ensure the ratification of key international legal instruments protecting the property rights of citizens in conditions of an armed conflict. In addition, the issue of status and guarantees for such persons very often become the subject of political speculation in the Ukrainian parliament. For example, for several years in the Verkhovna Rada of Ukraine there have been bills "On compensation for damage caused by a terrorist act" and "On compensation for damage caused to citizens by a terrorist act and as a result of an anti-terrorist operation". Adoption of these laws would enable to solve the problem of protecting property rights of citizens in conditions of external military aggression. This delay in the adoption is due to the reluctance of the state to bear the burden of compensation for property damage (Kolisnyk, 2019).

The problems of legislation described above are quite clearly disclosed at the level of practical cases. In this article, I would like to dwell on the case, which is tackled by lawyers of the Public organization Sich Human 
Rights Group (Dnipro). It is related to the protection of property rights of an internally displaced person, in particular compensation for reduced accommodation during hostilities. The essence of the case is that the person who lived in the city of Shakhtarsk in the Donetsk oblast, with the help of human rights activists, appealed to the court with a claim for compensation for material damage caused by Ukraine. The plaintiff's house was destroyed during city bombings in August 2014. At that time, the city of Shahtarsk was in an uncontrolled territory of Ukraine. No rescue service has left the city on fire; so many homes have simply been burned down. In addition, the plaintiff does not have documents that confirm the fact of the destruction of housing. After these events, the person turned to the police which opened the criminal proceeding. The plaintiff believes that there was a crime, in particular a terrorist act that caused significant damage to the property of an individual.

Moreover, the state of Ukraine, in the person of the Cabinet of Ministers of Ukraine, should bear responsibility for this crime, because according to the legislation, the authorities are responsible for carrying out the antiterrorist operation. In her claims, the person demanded to reimburse her the cost of the lost housing. However, given the lack of mechanisms to compensate for damage caused by an armed conflict, as already mentioned above, the court of first instance refused the person to comply with her claim, referring to the fact that the cause-effect relationship between the anti-terrorist operation and the destruction of the plaintiff's home was not proved in court. This decision was also taken as a result of the retaliation for the consequences of the armed conflict (Leheza et al., 2020).

Subsequently, the Person decided to appeal this decision to the appellate court, but the court upheld the decision as it did not find a violation of the substantive law. The court also expressed its position on the ungrounded claims of the plaintiff in the part of the evidence provided, which confirms the fault of the state of Ukraine. This situation arose from the fact that the state of Ukraine on the legislative level has obligated to indemnify property damage to the aggressor state. Having withdrawn personal responsibility, Ukraine essentially put judicial practice at a standstill, because the court is not able to make a decision in favor of the victims.

It should be noted that the problem is also complicated by the nonrecognition by Ukraine of documents issued by the authorities of selfproclaimed republics. For example, in similar situations in uncontrolled territories, such bodies compose acts of property destruction which in the future Ukrainian courts do not recognize as evidence. Moreover, the state has not developed an alternative system of fixing the consequences of an armed conflict.

Occasionally absolutely unique situations arise when an internally displaced person who defended the territorial integrity of Ukraine with 
Filatov Viktor, Sergey Herasymchuk, Oksana Zuieva, Oksana Tuieva y Dmytro Kartsyhin Protection of property rights of citizens in the conditions of foreign military aggression: political and legal experience of Ukraine

arms in the hands is asked to go to the temporarily occupied territory in order to obtain a documentary proof of ownership. For such a person, it means captivity and condemnation by militants. At present, human rights activists have sent a cassation appeal to the Supreme Court of Ukraine and demand the claim satisfaction and full compensation for the damage. In case of a negative decision, the next step will be to file a complaint with the European Court of Human Rights.

It can be noted that the imperfection of legislation in the area of the status of victims of armed conflicts actually makes it impossible to protect their property rights. The indicated case is just a separate example that demonstrates it. Due to the imperfection of the legislation, the development of the relevant judicial practice is also hindering, which negatively affects the reputation of the judicial system as a whole (Leheza et al., 2018).

\section{Conclusions}

Having systematized theoretical and practical aspects of the problem of protection of citizens' property rights in the conditions of external military aggression, we can propose the following ways of its solution:

- implementation of international humanitarian law (will increase the effectiveness of legal regulation of the status of victims of an armed conflict).

- adoption of a separate legislative act on the status of displaced persons and persons who have suffered as a result of terrorist activity and military aggression (will contribute to the elaboration of methods and forms to restore property rights).

- the introduction of clear and understandable criteria for assessing the property damage caused by an armed conflict (on the basis of which it will be possible to develop a mechanism for establishing causal links between loss of property and an armed conflict and a mechanism for compensation for such damage).

- elaboration and approval of a clear action plan within the framework of the Strategy for the Integration of Internally Displaced Persons (will allow to organize and coordinate the activities of executive authorities in implementing the state policy in the sphere of immigrants),

- establishing constructive cooperation with victims of an armed conflict and social protection bodies of the population (will allow to hardwire the interests of society and government). 
- depolarization of initiatives related to the status of victims of an armed conflict (will increase the authority of the authorities and weaken the social tension in Ukrainian society).

The problem of protecting property rights of citizens in the face of external military aggression is rather topical for the modern Ukrainian state. Since the beginning of the conflict in the east of Ukraine and the annexation of the Crimean peninsula, several years have passed, however, the state has not succeeded in building effective protection policies for the affected victims. This problem is relevant for the author of this article as well, since he is an internally displaced person himself and knows this situation perfectly. Today, several preconditions for the existence of this problem can be identified: political (the reluctance of the authorities to globally solve the problems of settlers); socio-economic (lack of financial resources to form a fund for compensation for property damage of the victims); organizational (lack of experience in the conditions of temporary occupation of territories); legal (imperfection of legislation and undeveloped legal practice); ideological (social alienation of immigrants which prevents defending their own rights and legitimate interests). Taken together, these preconditions led to a situation in which the affected person almost in most cases remains on their own with their problems, which is unacceptable in a social, legal state. However, recent government decisions and trends in practice provide grounds to assure that in the coming years this problem can be solved.

\section{Bibliographic References}

KOLISNYK, Sergey Pavlovich. 2019. "Legal provision of prevention of terrorism by national” In: European Reforms Bulletin. No. 3, pp. 28-32.

LAW OF UKRAINE. 2012. Some issues of full compensation for property forcibly alienated under the conditions of the legal regime of martial law or the state of emergency. Available online. In: https://zakon.rada.gov. ua/laws/show/998-2012-\%Do\%BF. Consultation date: 17/12/2020.

LAW OF UKRAINE. 2014. About the provision of monthly targeted assistance to internally displaced persons to cover the cost of living, including for payment of housing and communal services. Available online. In: https:// zakon.rada.gov.ua/laws/show/505-2014-\%Do\%BF. Consultation date: 19/12/2020.

LAW OF UKRAINE. 2014. On approval of the list of settlements on the territory of which the state authorities temporarily do not exercise their powers and the list of settlements located on the line of collision. Available 
Filatov Viktor, Sergey Herasymchuk, Oksana Zuieva, Oksana Tuieva y Dmytro Kartsyhin Protection of property rights of citizens in the conditions of foreign military aggression: political and legal experience of Ukraine

online. In: https://zakon.rada.gov.ua/laws/show/1085-2014-\%D1\%80. Consultation date: 17/12/2020.

LAW OF UKRAINE. 2014. On Approval of the Procedure for Using the Funds Received from Individuals and Legal Persons to Provide One-Time Cash Assistance to Victims and Internally Displaced Persons. Available online. In: https://zakon.rada.gov.ua/laws/show/535-2014-\%Do\%BF. Consultation date: 19/12/2020.

LAW OF UKRAINE. 2014. On Ensuring the Rights And Freedoms Of Citizens And Legal Regime In The Temporarily Occupied Territory. Available online. In: https://zakon.rada.gov.ua/laws/show/1207-VII_Consultation date: $18 / 12 / 2020$.

LAW OF UKRAINE. 2014. On Ensuring The Rights And Freedoms Of Internally Displaced Persons. Available online. In: https://zakon.rada.gov.ua/ laws/show/1706-18. Consultation date: 17/12/2020.

LAW OF UKRAINE. 2014. On Interim Measures For The Period Of The AntiTerrorist Operation. Available online. In: https://zakon.rada.gov.ua/ laws/show/1669-18. Consultation date: 17/12/2020.

LAW OF UKRAINE. 2015. On the Legal Regime of Military Status: 2015. Available online. In: https://zakon.rada.gov.ua/laws/show/1669-18. Consultation date: 17/12/2020.

LAW OF UKRAINE. 2015. On the Statement of the Verkhovna Rada of Ukraine "On the Suppression of Armed Aggression of the Russian Federation and Overcoming its Consequences. № 337-VIII. Available online: https:// zakon.rada.gov.ua/laws/show/337-19. Consultation date: 17/12/2020.

LAW OF UKRAINE. 2017. On Approval of the Strategy for the Integration of Internally Displaced Persons and Implementation of Long-Term Decisions on Internal Movement for the Period up to 2020. Available online. In: https://zakon.rada.gov.ua/laws/show/909-2017-\%D1\%80. Consultation date: 19/12/2020.

LAW OF UKRAINE. 2018. On the peculiarities of the state policy to ensure the state sovereignty of Ukraine in the temporarily occupied territories in the Donetsk and Luhansk oblasts. Available online. In: https://zakon.rada. gov.ua /laws/show/2268-19. Consultation date: 19/12/2020.

LAW OF UKRAINE. 2018. The issue of providing housing for internally displaced persons who defended the independence, sovereignty and territorial integrity of Ukraine. Available online. In: https://zakon.rada.gov.ua/ laws/show/280-2018-\%Do\%BF. Consultation date: 19/12/2020. 
LEHEZA, Yevhen; FILIPENKO, Tatiana; SOKOLENKO, Olha; DARAHAN, Valerii; KUCHERENKO, Oleksii. 2020. "Ensuring human rights in ukraine: problematic issues and ways of their solution in the social and legal sphere" In: Cuestiones políticas. Vol. 37, No. 64, pp. 123136. Available online. In: https://produccioncientificaluz. org/index.php/cuestiones/article/view/32210/33448. Consultation date: 19/12/2020.

LEHEZA, Yevhen; SAVIELIEVA, Maryna; DZHAFAROVA, Olena. 2018. "Structural and legal analysis of scientific activity regulation in developed countries" In: Baltic journal of economic studies. Vol. 4, No. 3, pp. 147157.

OSTAPENKO, Alexey Ivanovich. 2017. Anti-terrorism measures in Ukraine: administrative legal aspect In: Bulletin of the National University «Lviv Polytechnic». Vol. 810, pp. 43-48. 
Vol. 39 N $^{\circ} 69$

Esta revista fue editada en formato digital y publicada en julio de 2021, por el Fondo Editorial Serbiluz, Universidad del Zulia. Maracaibo-Venezuela 